\title{
CAN HIGH-ALTITUDE ICE MASSES IN TEMPERATE AREAS PROVIDE USEFUL CLIMATIC RECORDS? \\ (Abstract)
}

\author{
by
}

Paul A. Mayewski and W. Berry Lyons

(Glacier Research Group, Department of Earth Sciences, University of New Hampshire, Durham, New Hampshire 03824, U.S.A.)

Since 1979 we have been conducting a program of glaciochemical sampling and analysis in selected portions of the Indian Himalayas. The primary purpose of this work has been the retrieval of data that are of specific use in assessing the signal expressed by the chemistry of air masses entering the Himalayas. The techniques used for this purpose provide data sets for the following: chloride, sodium, reactive iron, reactive silicate, reactive phosphate, nitrite-plus-nitrate, ammonium, $\mathrm{pH}$, oxygen isotopes, deuterium, microparticles, total $\boldsymbol{\beta}$-activity, density and scanning electron microscopy. The results of this work appear in a series of papers (Lyons and others 1981, Lyons and Mayewski 1983, Mayewski and others 1981, 1983, 1984 and Goss and others 1985). In summary this work demonstrates: (1) problems encountered in high-altitude ice-core recovery, (2) effects of percolation on chemical records, (3) specific requirements necessary for the retrieval of unaltered glaciochemical records from Himalayan glaciers, (4) potential spatial variability of chemical species concentrations and interpretation of this with respect to time series, (5) usefulness of various glaciochemical indicators as applied to relative dating (seasonality) and air mass tracking, (6) specific details of the chemical and physical properties in Himalayan ice, and (7) recommendations for future Himalayan ice-core studies.

\section{REFERENCES}

Goss E, Mayewski P A, Lyons W B 1985 Examination of selected microparticles from the Sentik Glacier core, Ladakh Himalaya, India. Journal of Glaciology 31(108): 196-197

Lyons W B, Mayewski P A 1983 Nitrate plus nitrite concentrations in an Himalayan ice core. Geophysical Research Letters 10(12): 1160-1163

Lyons W B, Mayewski P A, Ahmad N 1981 Acidity of recent Himalayan snow. Proceedings of the Eastern Snow Conference, 38th annual meeting: 49-56

Mayewski P A, Lyons W B, Ahmad N 1981 Reconnaissance glaciochemical studies in the Indian Himalayas. Proceedings of the Eastern Snow Conference, 38th annual meeting: $45-48$

Mayewski P A, Lyons W B, Ahmad N 1983 Chemical composition of a high altitude fresh snowfall in the Ladakh Himalaya. Geophysical Research Letters 10(1): 105-108

Mayewski P A, Lyons W B, Ahmad N, Smith G, Pourchet M 1984 Interpretation of the chemical and physical time-series retrieved from Sentik Glacier, Ladakh Himalaya, India. Journal of Glaciology 30(104): 66-76 